\title{
Detection of Proteolysis in Milk by Pseudomonas fluorescens Using Urea PAGE Method
}

\author{
Chove Lucy Mlipano (Corresponding author) \\ Sokoine University of Agriculture (SUA), Department of Food Technology, Nutrition \\ and Consumer Sceinces, P.O.Box 3006, Morogoro, Tanzania. E-mail: \\ lucychove@suanet.ac.tz; lucychove@yahoo.co.uk
}

\section{Grandison Alistair}

University of Reading, Department of Food and Nutritional Sciences, P.O. Box 226, Reading RG6 6AP, UK. E-mail: a.s.grandison@reading.ac.uk

\section{Lewis Michael}

University of Reading, Department of Food and Nutritional Sciences, P.O. Box 226, Reading RG6 6AP, UK. E-mail: m.j.lewis@reading.ac.uk

Received: October 20, 2017 Accepted: December 26, 2017 Published: December 28, 2017

doi:10.5296/jfs.v7i1.12019 URL: https://doi.org/10.5296/jfs.v7i1.12019

\begin{abstract}
Proteolysis of milk during storage by two strains of Pseudomonas NCIMB 702085 (414) and NCIMB 701274 (416) was investigated using the Urea PAGE method. Pseudomonas fluorescens enzymes were also extracted and purified by dialysis before inoculation into UHT skim milk in an attempt to partially purify the enzyme. Results showed that dialysis removed some peptides and amino acids which would interfere with the assay procedure. The method also confirmed that Pseudomonas fluorescens NCIMB 701274 (416) was more proteolytic than Pseudomonas NCIMB 702085 (414). Thus, Urea PAGE is a useful method for monitoring proteolysis in milk by Pseudomonas fluorescens.
\end{abstract}

Keywords: Proteolysis, Pseudomonas fluorescens, Dialysis, Urea PAGE, UHT milk 


\section{Macrothink}

\section{Introduction}

Proteolytic enzymes are of great importance to the dairy industry because they are responsible for imparting desirable or undesirable properties to dairy products through changes in flavour and texture (Datta \& Deeth, 2003). Proteolytic enzymes that cause problems in milk and dairy products are of two major types, milk proteinases which naturally occur in all milk, and bacterial proteinases produced by contaminating bacteria (Nielsen, 2002). Proteolysis in refrigerated milk is usually caused by Gram negative psychrotrophs. Of these, Pseudomonas spp. are predominant.

Psychrotrophic microorganisms are predominant in raw milk microbiota during the storage, producing hydrolytic enzymes such as proteases and lipases which are responsible for many quality issues, for example; defects and deterioration, resulting in the limited shelf-life of dairy products (Chen et al., 2003). These hydrolytic enzymes detected in skim milk are of particular concern, indicating that they could be produced by Pseudomonas sp. during the cold storage of raw milk, contributing to the spoilage problem in milk and dairy products (Corre et al., 2011). Although psychrotrophs are usually destroyed by heat treatments, the extracellular endometalloproteases enzymes produced by these microorganisms are usually thermostable, keeping their activities even after pasteurization and even ultra-high temperature (UHT) treatments (Datta \& Deeth, 2003; Kohlmann et al., 1991; Stepaniak, 2004). As a result, spoilage in milk may occur after pasteurisation and, more likely, after UHT heat treatment. Enzymatic spoilage without concomitant bacterial growth is of special concern in UHT milks (Gaucher et al., 2011). As these enzymes are not commercially available, one aim of this research was to extract them followed by partial purification before inoculation into UHT skim milk.

In this study, the Urea PAGE method was used to monitor proteolysis by two strains of Pseudomonas fluorescens, which were inoculated into milk.

\section{Materials and Methods}

\subsection{UHT Milk}

Commercial UHT skimmed milk was supplied by Dairy Crest, Shropshire, UK, and utilised within two weeks of buying.

\subsection{Bacterial Strains}

Two strains of Pseudomonas fluorescens (NCIMB 702085 and NCIMB 701274) were inoculated into skimmed UHT milk to study their effect on proteolysis. These strains were obtained from the departmental stock culture (Department of Food and Nutritional Sciences, University of Reading, UK), maintained at $-80^{\circ} \mathrm{C}$. They were grown overnight in nutrient broth followed by overnight agar slants at $30^{\circ} \mathrm{C}$. Streaking at $30^{\circ} \mathrm{C}$ for $24 \mathrm{~h}$ was carried out to check purity of samples followed by Gram staining. Both strains were grown on nutrient agar with CFS (cetrimide fucidin cephaloridine) at $30^{\circ} \mathrm{C}$ for $24 \mathrm{~h}$ to confirm the fluorescence characteristics of Pseudomonas fluorescens. Positive strains were incubated in plate count agar (PCA) at $30^{\circ} \mathrm{C}$ for $24-48 \mathrm{~h}$ followed by microbial counting. An overnight culture was grown on nutrient broth and inoculated into skimmed UHT milk for the detection of proteolysis. Samples were stored at $20^{\circ} \mathrm{C}$ for 7 days. Unless otherwise stated, all materials were from Fisher (Fisher 


\section{Macrothink}

Scientific UK Ltd, Leicestershire, UK).

\subsection{Urea PAGE}

The protocol was based on Laemli (1970).

\section{Samples and markers preparations}

Samples: $100 \mu \mathrm{L}$ of samples were mixed with $400 \mu \mathrm{L}$ of reducing sample buffer. These were allowed to stand in boiling water for $2 \mathrm{~min}$ and allowed to cool to $25^{\circ} \mathrm{C}$ before loading into the gel.

Markers: Low molecular weight markers ranging between 6.5-66 kDa (Sigma-Aldrich Gillingham, UK) were prepared as follows: A vial containing low molecular weight markers was reconstituted with $100 \mu \mathrm{L}$ of deionised water. To ensure complete dissolution of the chemical, the vial was vortexed for a few seconds. The markers were dispensed in Eppendorf vials in aliquots and any unused portion was stored at $-18^{\circ} \mathrm{C}$ until required. The proteins in the low molecular weight marker were as follows: albumin, bovine serum (66 kDa); ovalbumin from chicken egg (45 kDa); glyceradehyde-3-phosphate dehydrogenase from rabbit muscle (36 $\mathrm{kDa})$; carbonic anhydrase from bovine erythrocytes $(29 \mathrm{kDa})$; trypsinogen from bovine pancrease $(24 \mathrm{kDa})$; trypsin inhibitor from soybean $(20 \mathrm{kDa}) ; \alpha$-lactalbumin from bovine milk $(14.2 \mathrm{kDa})$ and aprotinin from bovine lung $(6.5 \mathrm{kDa})$

\section{Reagents and solutions}

Acrylamide-bisacrylamide stock solution (40\% T): (Sigma-Aldrich Gillingham, UK): The solution was used directly from the bottle.

Separating gel buffer (0.5 M Tris, pH 8.8): Tris base (12.86 g) and $77.14 \mathrm{~g}$ Urea (77.14 g) was dissolved in $200 \mathrm{~mL}$ distilled water and $\mathrm{pH}$ adjusted to 8.8 with $5 \mathrm{M} \mathrm{HCl}$. The solution was stored at $4{ }^{\circ} \mathrm{C}$.

Stacking gel buffer (0.07 M Tris, pH 7.6): Tris base (1.66 g) was dissolved in $200 \mathrm{~mL}$ of distilled water. $\mathrm{pH}$ was adjusted to 7.6 with $5 \mathrm{M} \mathrm{HCl}$ and stored at $4{ }^{\circ} \mathrm{C}$.

Electrode buffer: Tris base $(1.5 \mathrm{~g})$ and glycine $(7.3 \mathrm{~g})$ were dissolved in $1000 \mathrm{~mL}$ of distilled water. No $\mathrm{pH}$ adjustment was made (the $\mathrm{pH}$ was 8.3 ). The solution was freshly prepared and cooled to $4{ }^{\circ} \mathrm{C}$ for at least 3 hours before use.

Reducing sample buffer: Tris base ( $0.75 \mathrm{~g})$ and Urea $(49 \mathrm{~g})$ were dissolved in $100 \mathrm{~mL}$ distilled water and $\mathrm{pH}$ adjusted to 7.6 with $5 \mathrm{M} \mathrm{HCl}$. $\beta$-mercaptoethanol $(0.7 \mathrm{~mL})$ and $0.9 \mathrm{~g}$ of bromophenol blue were added. The solution was stored at $4{ }^{\circ} \mathrm{C}$.

Ammonium persulphate (10\% APS): This solution was freshly prepared by dissolving $0.1 \mathrm{~g}$ of APS in $1 \mathrm{~mL}$ of distilled water.

Sodium Dodecyl Sulphate (10\% SDS): SDS (10 g) was dissolved in $100 \mathrm{~mL}$ distilled water and stored at $25^{\circ} \mathrm{C}$.

N,N,N',N'-Tetramethylenediamide- TEMED (Sigma-Aldrich Gillingham, UK): This was used directly from the bottle.

Staining solution: Coomasie blue G250 (1 g) was dissolved in $400 \mathrm{~mL}$ methanol, $100 \mathrm{~mL}$ acetic acid and the volume made up to $1000 \mathrm{~mL}$ with distilled water. It was stored at $25^{\circ} \mathrm{C}$.

Destaining solution: To $400 \mathrm{~mL}$ of methanol, $100 \mathrm{~mL}$ of acetic acid was added and the volume made up to $1000 \mathrm{~mL}$ with distilled water 


\section{Macrothink}

Preparation of the gel

\section{Reagents}

Separating Gel buffer (mL)

Stacking Gel buffer (mL)

$40 \%$ acrylamide solution $(\mathrm{mL})$

$10 \% \operatorname{SDS}(\mu \mathrm{L})$

TEMED $(\mu \mathrm{L})$

10\% APS $(\mu \mathrm{L})$

Total volume (mL)

\section{2\% Separating Gel}

7.0

$-$

3.00

100.0

10.0

50.0

10.160

\section{4\% Stacking Gel}

4.50

0.5

5.0

25.0

5.030

\section{Experiments:}

Inoculation of Pseudomonas fluorescens into UHT milk to monitor proteolysis

The effect of storage time on proteolysis was studied at $37^{\circ} \mathrm{C}$ for $24 \mathrm{~h}$. Pseudomonas fluorescens strains were inoculated into UHT skim milk followed by incubation at $37^{\circ} \mathrm{C}$ for 24 $\mathrm{h}$ to monitor proteolysis. Control samples without added bacteria were also prepared. All experiments were carried out at the natural $\mathrm{pH}$ of the milk (6.6-6.7), unless stated otherwise.

Following proteolysis, breakdown products were analysed by Urea PAGE method. Prior to analysis, all milk samples were heated at $100^{\circ} \mathrm{C}$ for $10 \mathrm{~min}$ and held in a water bath (Grant Instruments Cambridge Ltd, Cambridge, UK) to denature the whey proteins. The Urea-PAGE protocol (Bio-Rad Labs, Richmond, California, USA) was used in which $100 \mu \mathrm{L}$ of non-clarified samples were mixed with $400 \mu \mathrm{L}$ reducing sample buffer. These were left to stand in warm water at $45^{\circ} \mathrm{C}$ for $5 \mathrm{~min}$ and allowed to cool in water to $25^{\circ} \mathrm{C}$ before they were loaded onto $12 \%$ gels. Staining was by Coomasie brilliant blue G 250 mixed with methanol and acetic acid, whereas de-staining was done by use of methanol and acetic acid.

This experiment was set up to monitor casein degradation following inoculation of Pseudomonas fluorescens 414 and 416 into UHT skimmed milk and incubated for $24 \mathrm{~h}$ but sampled at 2 and $24 \mathrm{~h}$. Milk proteins may be identified by PAGE since the individual proteins can be separated according to size, or charge to mass ratio. This protocol was selected because the SDS-PAGE does not resolve the 4 caseins properly. The molecular weights of the 4 caseins are as follows: $\alpha_{\mathrm{s} 1}$-caseins- $23 \mathrm{kDa} ; \alpha_{\mathrm{s} 2}$-caseins $-25 \mathrm{kDa} ; \beta$ - casein $-24 \mathrm{kDa}$ and $\kappa$-caseins -19 $\mathrm{kDa}$ (Fox, 2003). The Urea PAGE method is more appropriate because despite the close molecular weight range, it can resolve the casein accordingly. Separation by Urea-PAGE is based on charge to mass ratio.

Extraction and inoculation of Pseudomonas fluorescens enzymes into UHT milk to monitor proteolysis

A separate experiment was carried out where enzymes from both strains of Pseudomonas fluorescens NCIMB 702085 and NCIMB 701274 were extracted and cultured into UHT skimmed milk, followed by incubation at $37^{\circ} \mathrm{C}$ for 3 days. Cells were removed by centrifugation $\left(24,000 \mathrm{~g}\right.$ for $10 \mathrm{~min}$ at $\left.5^{\circ} \mathrm{C}\right)$, resulting in a clear supernatant which contained the active enzyme. The crude enzyme extract was stored at $-20^{\circ} \mathrm{C}$ prior to purification. To further purify the enzyme, the supernatant was dialysed against distilled de-ionised water 


\section{$\triangle$ Macrothink}

(with $0.05 \%$ sodium azide). Dialysis was performed to remove peptides and amino acids from the enzyme, which would interfere with the assaying procedures. Ten $\mathrm{mL}$ of crude enzyme extract from each of the two strains of Pseudomonas fluorescens were dialysed in 14 $\mathrm{kDa}$ molecular weight cut-off tubular porous membrane (Medicell International Ltd., London, UK). The tubes were clipped securely and placed in $1500 \mathrm{~mL}$ of distilled water at $20^{\circ} \mathrm{C}$ for $24 \mathrm{~h}$, with one change of water. The semi-purified enzyme was inoculated into UHT skimmed milk and incubated for $24 \mathrm{~h}$. Samples without added enzyme acted as controls. Samples were drawn after 2, 6 and $24 \mathrm{~h}$ to be analysed by gel electrophoresis.

To determine the optimum enzyme concentration, various concentrations of the enzyme extracts $[5 \%, 10 \%$ and $20 \%(\mathrm{v} / \mathrm{v})]$ were inoculated into UHT skimmed milk prior to incubation at $37^{\circ} \mathrm{C}$ for 2 and $24 \mathrm{~h}$ followed by analysis by gel electrophoresis. The selected levels were based on a study by Lee (2006) who indicated that 5-25\% enzyme extracts could be used for proteolysis. After preliminary studies (results not shown), a level of $10 \%$ enzyme extract was considered appropriate for further study, as readily detectable results were obtained.

Electrophoretograms were used for qualitative monitoring of the degree of proteolysis in milk by Urea PAGE method. No quantitative methods were employed in this study.

\section{Results}

Results obtained were as shown on Figures 1, 2 and 3. In Figure 1, milk samples which had been inoculated with the two strains of $P$. fluorescens and incubated for $24 \mathrm{~h}$ at $37^{\circ} \mathrm{C}$ were monitored. Initial results indicated that one strain was more proteolytic than the other. This is important information for milk samples during storage as some strains could result in spoilage within a very short time as compared to others. In Figure 2, UHT milk that had been inoculated with 5, 10 and $20 \%$ enzymes of one strain of $P$. fluorescens 414 and incubated at $37^{\circ} \mathrm{C}$ for $24 \mathrm{~h}$ was observed. This was done so as to find an optimum level of enzyme to be used for inoculation after dialysis. Figure 3 shows an electrophoretogram of $10 \%$ dialysed sample of $P$. fluorescens enzymes and its suitability in monitoring proteolysis by both strains of $P$. fluorescens..

\section{Discussion}

\subsection{Proteolysis Caused by Pseudomonas fluorescens}

Preliminary experiments indicated that the number of viable cells in the stock (inocula) from the departmental culture of Pseudomonas fluorescens was $10^{7}-10^{8}$ cfu per mL. It was reported that a psychrotrophs population of $10^{4} \mathrm{cfu} / \mathrm{mL}$ is sufficient to induce proteolysis in milk (Renner, 1988). In the current experiments, about $10^{5}-10^{6} \mathrm{cfu} / \mathrm{mL}(1 \% \mathrm{v} / \mathrm{v})$ was inoculated into UHT skimmed milk to initiate proteolysis.

Storage time had a significant effect on proteolysis of the inoculated samples. The low but constant proteolysis in the control sample was probably due to native enzymes. Many factors are involved in protease production and proteolysis. It has been documented that, although there are contradictory reports regarding the quantity of enzyme produced and the activity of the microorganisms, the strain of the bacteria was regarded as crucial factor in determining proteolysis and not their number (Haryani et al., 2003; Hankin \& Shields, 1983). Thus, milk with higher psychrotroph count did not necessarily have higher proteolysis than those with 


\section{Macrothink}

lower counts. However, it was emphasised that minimum bacterial counts at which bacterial proteinases can be produced must be monitored (Haryani et al., 2003). Other researchers have suggested that the extent of proteolysis of milk proteins by enzymes depended on the number of target sites available for each enzyme and on the accessibility of these target peptide bonds by proteases. Moreover, control samples had lower absorbance values, confirming that levels of native proteases were probably too low to cause significant proteolysis.

Figure 1 shows that with increased incubation time greater hydrolysis of caseins was observed. The $\beta$-caseins were preferably hydrolysed at $2 \mathrm{~h}$ incubation, whereas $\alpha-\mathrm{s}_{1}$ and $\alpha$-s $\mathrm{s}_{2}$ casein were also hydrolysed after $24 \mathrm{~h}$. It was also obvious that Pseudomonas fluorescens 416 enzyme had faint bands of $\alpha-s_{1}, \alpha-s_{2}$ casein and $\beta$-caseins at all incubation times, indicating more degradation and higher enzyme activity than Pseudomonas fluorescens 414 enzymes.

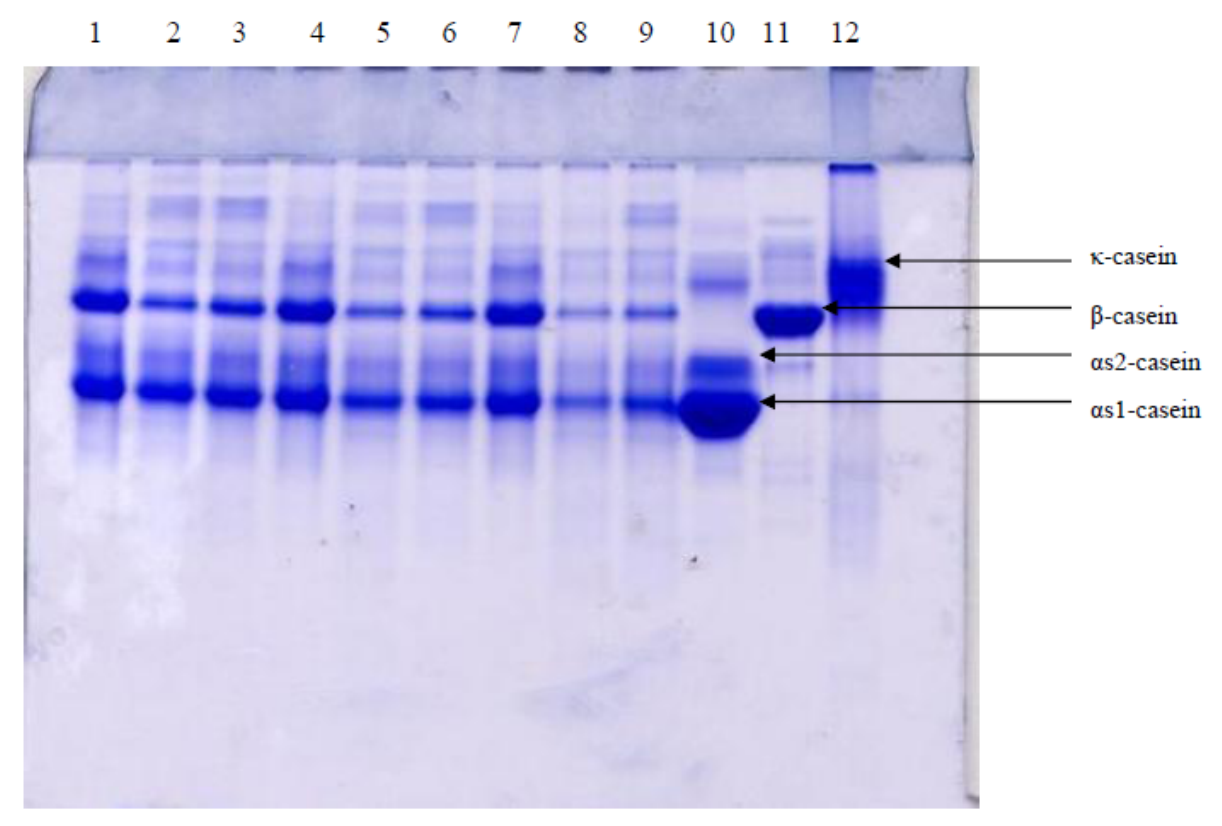

Figure 1. Urea PAGE electrophoretogram ( $\mathrm{T}=12 \%, \mathrm{C}=4 \%)$ Pseudomonas fluorescens enzymes incubated in UHT skimmed milk at $37^{\circ} \mathrm{C}$ for 2 and $24 \mathrm{~h}$

Legend: Lanes 1-3: Pseudomonas fluorescens 414 at 5\%, 10\% and 20\% in UHT skimmed milk after $2 \mathrm{~h}$ incubation at $37^{\circ} \mathrm{C}$. Lane 4: Empty lane Lane $5-7$ : Pseudomonas fluorescens 414 at $5 \%, 10 \%$ and $20 \%$ in UHT skim milk after $24 \mathrm{~h}$ incubation at $37^{\circ} \mathrm{C}$. Lanes 8 : empty lane Lanes 9-11: $\alpha$ - casein, $\beta$ - casein, $\kappa$ - casein and Lane 12: a mixture of $\alpha, \beta, \kappa$ caseins respectively.

The caseins in control samples were not degraded (lanes 1, 4 and 7). Comparison between inoculated samples and the controls confirmed preference for Pseudomonas fluorescens 416 (lanes 5 and 8) which degraded $\beta$-casein. There was also gradual disappearance of $\alpha \mathrm{s}_{1}$ and $\alpha \mathrm{s}_{2}$-caseins which was most evident after $24 \mathrm{~h}$ on lane 8 . Although $\kappa$-casein has shown some degradation, its poor resolution in the gel makes it difficult to conclude on the extent of hydrolysis. 


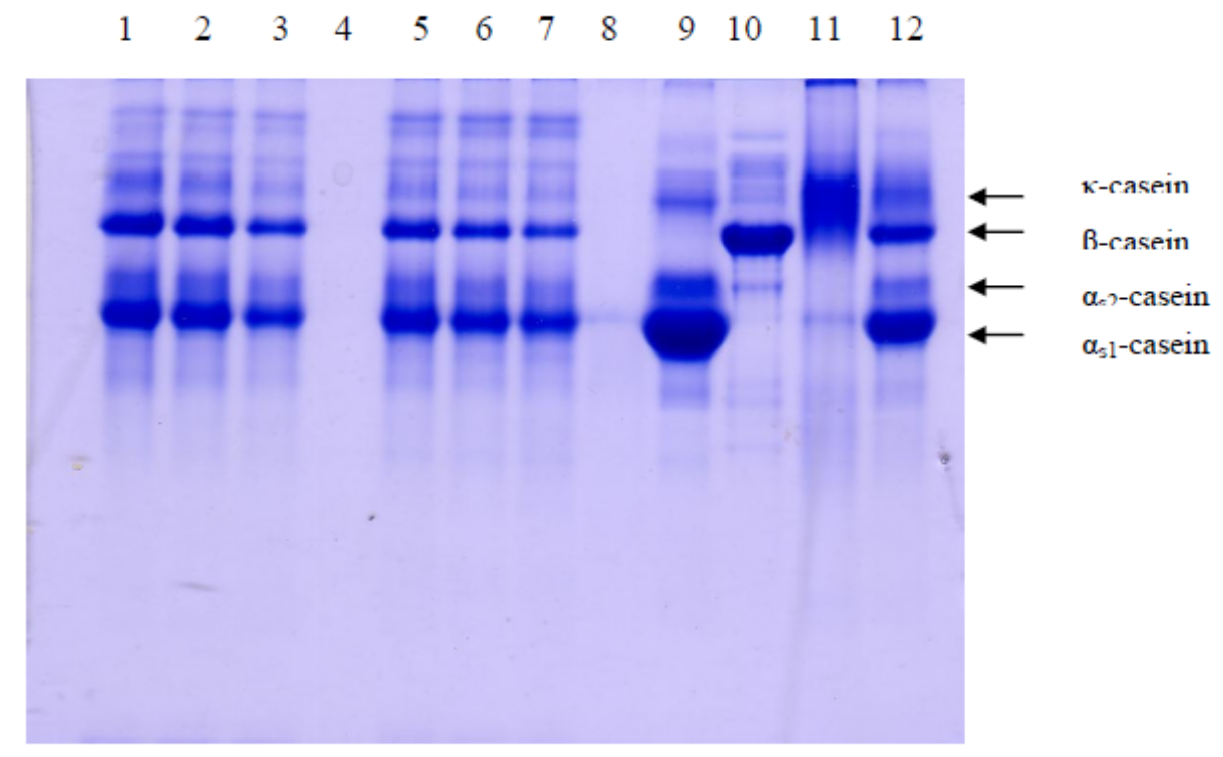

Figure 2. Urea PAGE electrophoretogram $(\mathrm{T}=12 \%, \mathrm{C}=4 \%)$ Pseudomonas fluorescens enzymes incubated in UHT milk at $37^{\circ} \mathrm{C}$ for 2 and $24 \mathrm{~h}$

Legend: Lanes 1-3: Pseudomonas fluorescens 414 at 5\%,10\% and 20\% in UHT skim milk after $2 \mathrm{~h}$ incubation at $37^{\circ} \mathrm{C}$. Lane 4: Empty lane Lane 5-7: Pseudomonas fluorescens 414 at $5 \%, 10 \%$ and $20 \%$ in UHT skim milk after $24 \mathrm{~h}$ incubation at $37^{\circ} \mathrm{C}$. Lanes 8: empty lane Lanes 9-11: $\alpha$ - casein, $\beta$ - casein, $\kappa$ - casein and Lane 12: a mixture of $\alpha, \beta, \kappa$ caseins respectively.

Figure 2 shows the effect of incubating the various concentrations of $P$. fluorescens 414 at 5\%, $10 \%$ and $20 \%$ for 2 and $24 \mathrm{~h}$ at $37^{\circ} \mathrm{C}$ on proteolysis. As expected, the bands for $P$. fluorescens 414 were denser at $2 \mathrm{~h}$ incubation for all concentrations studied compared to $24 \mathrm{~h}$ of incubation indicating advanced levels of proteolysis. The $\alpha_{\mathrm{s} 1}$-casein bands were denser than the $\beta$ - and $\alpha_{\mathrm{s} 2}$-casein bands, indicating preference of $P$. fluorescens to hydrolyse $\beta$-caseins over $\alpha_{\mathrm{s} 1}$ and $\alpha_{\mathrm{s} 2}$-caseins especially after $24 \mathrm{~h}$ of incubation. Proteolysis was most evident at $20 \%$ enzyme concentration where both $\beta$ - and $\alpha_{\mathrm{s} 2}$-caseins were hydrolysed. The $\kappa$-casein band, though very faint, gradually decreased in intensity from lanes 1-6 confirming its hydrolysis by $P$. fluorescens.

In a study by Chove et al., (2011) analysis of proteolysis by plasmin enzyme on day 7, showed completely disappearance of both the $\alpha$ - and $\beta$-casein bands, indicating extensive proteolysis on these caseins. Microbial enzymes have been reported to show preference to hydrolyse $\kappa$-casein, which is usually found on the surface of the casein with the formation of para- $\kappa$ casein (Snoeren \& Van Riel, 1979), followed by extensive hydrolysis which is non-specific (Law et al., 1977). Other authors have also documented that $\kappa$-casein is the ideal substrate for bacterial proteolysis (Fairbairn \& Law, 1986; Datta \& Deeth, 2003). However, in one study it was revealed that different strains of Pseudomonas spp. showed different hydrolysis rates on caseins whereby some degraded whole casein more than $\alpha, \beta$ or $\kappa$-casein while others degraded $\beta$-casein more than $\alpha$ and $\kappa$-casein (Mitchell \& Marshall, 1989). A study of 6 proteases revealed that 3 were more active against $\alpha$-casein than whole casein, $\gamma, \beta$ or $\kappa$ - casein; 


\section{Macrothink}

and in another study, $\alpha$-casein and whole casein were hydrolysed to the same extent (Patel et al., 1986). It was stipulated that whole casein could have a configuration that made it more susceptible to enzyme action (Mitchell and Marshall, 1989). The caseinolytic potential of these proteases is highly variable and strain dependent (Dufour et al., 2008). Some studies have been performed to understand the proteolytic activities on the milk proteins and especially on the casein molecules. Koka and Weimer (2000) indicated that a protease isolated from $P$. fluorescens RO98 preferentially hydrolysed $\kappa$-casein in artificial casein micelles. With the same objective, Costa et al., (2002) showed that an extract of $P$. fluorescens RV10 culture proteolysed both $\kappa$ and $\beta$-casein. A study by Nicodème et al., (2005) characterized an extracellular protease from Pseudomonas aureofaciens LBSA1 and identified some peptidic bonds which had been cleaved by this enzyme on different purified casein molecules. However, all these studies were only performed on model systems with more or less purified enzyme and hence more studies need to be conducted using purified enzyme extracts.

It has also been stated that a great deal of variability observed in the ability of the proteases to hydrolyse $\kappa$-casein is due to conformational differences in proteins that can affect substrate specificity. As previously explained, the various strains of Pseudomonas fluorescens have different preferences for hydrolysing caseins. The $\gamma$-caseins are a result of the activity of native enzymes (presumably plasmin) on $\beta$-caseins. As expected, the bands are fainter after $24 \mathrm{~h}$ than after $2 \mathrm{~h}$ because of the longer time of incubation and hence enzyme activity.

\subsection{Proteolysis Caused by Dialysed Pseudomonas fluorescens Enzymes}

Figure 3 shows the effect of incubating dialysed concentrations of enzymes from NCIMB 701274 (414) and NCIMB 702085 (416) strains for 6 and $24 \mathrm{~h}$ at $37^{\circ} \mathrm{C}$ by Urea PAGE. Preference for $\beta$-casein degradation over $\alpha_{s-1}$ and $\alpha_{s-2}$ was evident for both strains especially after $24 \mathrm{~h}$ of incubation.

Incorporation of Urea into the samples permits the separation of most caseins and reveal the removal of phosphate groups from individual caseins (Bingham et al., 1976), and thus this method was recommended to monitor proteolysis of caseins during the ageing of cheeses. Hekken and Thompson (1992) observed that 40\% dephosphorylation of whole casein slowed down the migration rate compared to the native $\beta$-casein. The authors explained that the removal of negatively charged phosphate groups slowed down the migration rate of the protein on the gels. The same researchers also found that $\kappa$-casein was poorly resolved in the gel, an observation which was also made in the current study.

The figure below shows the breakdown of proteins in milk by $P s . f l$. enzymes 


\section{I Macrothink}

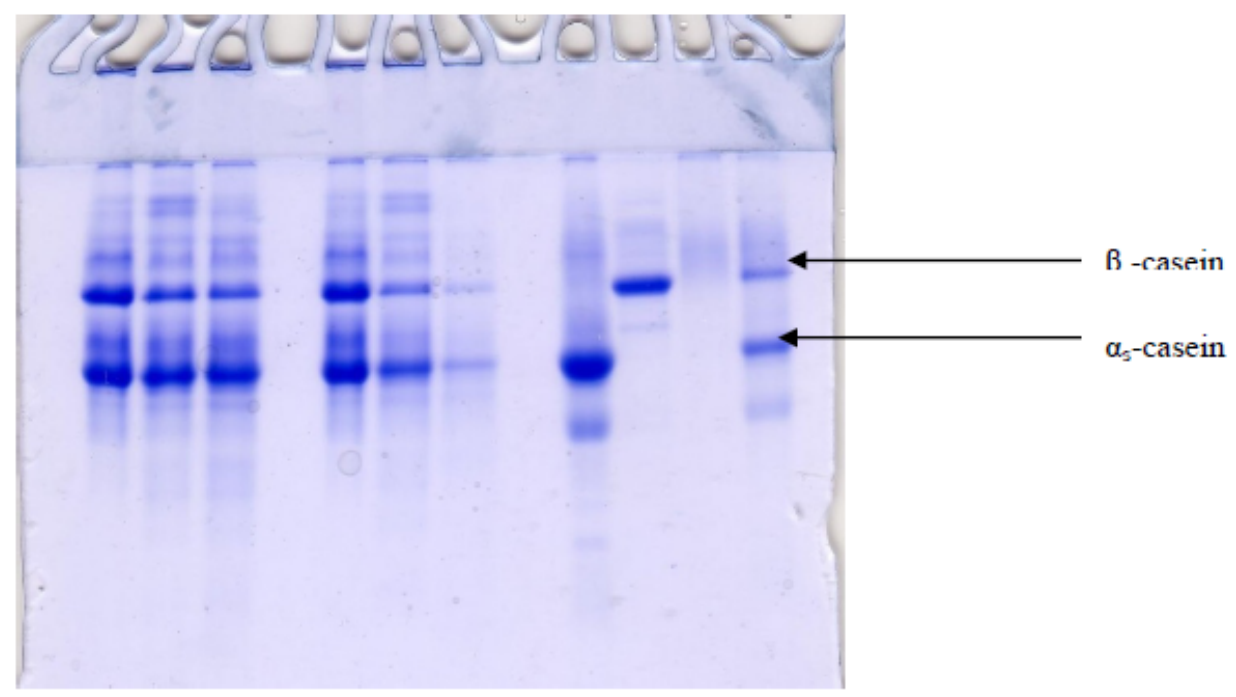

Figure 3. Urea PAGE electrophoretogram $(\mathrm{T}=12 \%, \mathrm{C}=4 \%)$ of dialysed Pseudomonas fluorescens (10\%) enzymes incubated in UHT milk at $37^{\circ} \mathrm{C}$ for 6 and $24 \mathrm{~h}$

Legend: Lanes 1-3: Control (UHT milk) Ps. $f l$. enzyme 414 and Ps. $f l$. enzyme 416 at $6 \mathrm{~h}$ Lane 4: Empty lane Lanes 5-7: Control, $P$ s. $f l$. enzyme 414 and $P s$. $f l$. enzyme 416 incubated for $24 \mathrm{~h}$. Lane 8: Empty lane Lanes 9 -11: $\alpha-\left(\mathrm{s}_{2 \& \mathrm{~s}}\right)$; $\beta$ - and $\kappa$-casein respectively Lane 12: $\alpha-(s 2 \& s 1) ; \beta$ - and $\kappa$-casein.

UHT skimmed milk inoculated with dialysed Pseudomonas fluorescens 414 and 416 enzymes (10\%), indicated that the dialysis procedure further purified the samples since the breakdown products in dialysed samples were lower after $24 \mathrm{~h}$ than the non-dialysed samples (Figures 1 and 3).

Inoculating the milk with live Pseudomonas fluorescens presented problems because other microorganisms could grow in milk as no sodium azide was added. Hence, Pseudomonas fluorescens enzymes were dialysed against water, so as to remove peptides and amino acids which could interfere with the analytical procedures. Addition of partially purified enzyme into milk is a useful tool because sodium azide, which controls growth of microorganisms, can be used. Hence, by adding Sodium azide, no additional bacterial proteases could be produced on storage and thus only proteases that survived treatments could act on caseins.

Enzyme purification by dialysis removes the peptides and amino acids that are associated with the enzyme preparation (Schokker \& Van Boekel, 1997). Further purification of the Ps. $f l$. enzyme by ammonium sulphate precipitation was carried out by some researchers and this was found to increase the specific activity by 13 fold (Schokker \& VanBoekel, 1997). This is recommended in future studies.

\section{Conclusion}

This study focused on the role of $P$. fluorescens and their enzymes on proteolysis in UHT 


\section{MInstitute Macrothink $_{\text {Int }}$}

skimmed milk by Urea PAGE. Results showed that proteolysis increased with storage time. These properties are exploited in Urea-PAGE method.

Urea PAGE method is a useful qualitative method to observe breakdown profiles of caseins by microbial enzymes. $P$. fluorescens showed preference for degradation of $\beta$-casein over $\alpha_{\mathrm{s} 1}$ and $\alpha_{\mathrm{s} 2}$ caseins. It was also revealed that $P$. fluorescens 416 was more proteolytic than $\mathrm{P}$. fluorescens 414, which was more evident after 24 hours of incubation.

Partial purification of $P$. fluorescens enzyme by dialysis was found to be an effective method in removing interfering substances and hence better method for monitoring proteolysis. Thus, it may be concluded that Urea PAGE method is a useful procedure for monitoring proteolysis in milk by both strains of $P$. fluorescens.

\section{References}

Bingham, E. W., Farell, H. M., \& Dahl, K. J. (1976). Removal of Phosphate groups from caseins with potato acid phosphate. Biochimica et Biophysica Acta, 429(2), 448-460. https://doi.org/10.1016/0005-2744(76)90293-X

Bio-Rad Labs, Mini-PROTEAN III electrophoresis cell. Instruction manual. Richmond, California, USA.

Chen, L., Daniel, R. M., \& Coolbear, T. (2003) Detection and impact of protease and lipase activities in milk and milk powders. International Dairy Journal, 13, 255-275. https://doi.org/10.1016/S0958-6946(02)00171-1

Chove, L. M., Grandison, A. S., \& Lewis, M. J. (2011). Comparison of the methods for analysis of proteolysis by plasmin in milk. Journal of Dairy Research, 78, 184-190. https://doi.org/10.1017/S0022029911000094

Corrêa, A. P. F., Daroit, D. J., Velho, R. V., \& Brandelli, A. (2011). Hydrolytic potential of a psychrotrophic Pseudomonas isolated from refrigerated raw milk. Brazilian Journal of Microbiolology, 42(4), 1479-1484. https://doi.org/10.1590/S1517-83822011000400034

Costa, M., Gomez, M. F., Molina, L. H., Simpson, R., \& Romero, A. (2002). Purification and characterization of proteases from Pseudomonas fluorescens and their effect on milk proteins. Archivos Latinoamericanos de Nutricion, 52,160-166.

Datta, N., \& Deeth, H. C. (2003). Diagnosing the cause of proteolysis in UHT milk. $\begin{array}{llll}\text { Lebensmittel-Wissenschaft } \quad \text { und } \quad \text { Technologie, } & 36, & 173-182 .\end{array}$ https://doi.org/10.1016/S0023-6438(02)00214-1

Dufour, D., Nicodème, M., Perrin, C., Driou, A., Brusseaux, E., Humbert, G., Gaillard, J. L., \& Dary, A. (2008). Molecular typing of industrial strains of Pseudomonas spp. isolated from milk and genetical and biochemical characterization of an extracellular protease produced by one of them. International Journal of Food Microbiology, 125, 188-19. https://doi.org/10.1016/j.ijfoodmicro.2008.04.004

Fairbairn, D. J., \& Law, B. A. (1986). Proteinases of pschrotrophic bacteria: their production, properties. effects and control. Journal of Dairy Research, 53, 139-177. https://doi.org/10.1017/S0022029900024742

Gaucher, I., Tanguy, G., Fauquant, J., Jardin, J., Rousseau, F., Robert, B., Madec, M.-N., \& Gaucheron, F. (2011). Proteolysis of casein micelles by Pseudomonas fluorescens CNRZ 798 


\section{$\triangle$ Macrothink}

contributes to the destabilisation of UHT milk during its storage. Dairy Science Technology, 91, 413-429. https://doi.org/10.1007/s13594-011-0019-4

Hankin, L., \& Shields, D. (1983). Keeping quality and flavor, and microorganisms, proteases and lipases in raw cow and goat milk at collection and after storage. Journal of Food Protection, 46, 873-877. https://doi.org/10.4315/0362-028X-46.10.873

Haryani, S., Datta, N., Elliot, A. J., \& Deeth, H. C. (2003) Production of proteinases by psychrotrophic bacteria in raw milk stored at low temperature. The Australian Journal of Dairy Technology, 58, 15-20.

Hekken, D. L. V., \& Thompson, M. P. (1992). Application of PhastSystem to the resolution of Bovine milk proteins an Urea- Polyacrylamide Gel Electrophoresis. Journal of Dairy Science, 75, 1204-1210. https://doi.org/10.3168/jds.S0022-0302(92)77868-0

Kohlmann, K. L., Nielsen, S. S., \& Ladisch, M. R. (1991). Purification and characterisation of an extracellular protease produced by Pseudomonas fluorescens M3/6. Journal of Dairy Science, 74, 4125-4136. https://doi.org/10.3168/jds.S0022-0302(91)78607-4

Koka, R., \& Weimer, B. C. (2000) Isolation and characterization of a protease from Pseudomonas fluorescens RO98. Journal of Applied Microbiology, 89, 280-288. https://doi.org/10.1046/j.1365-2672.2000.01108.x

Laemli, U. K. (1970). Cleavage of structural proteins during the assembly of the head of bacteriophage. Nature, 227, 680-685. https://doi.org/10.1038/227680a0

Law, B. A. (1979). Reviews on the progress of Dairy Science: Enzymes of pschrotrophic bacteria and their effects on milk and milk products. Journal of Dairy Research, 46, 573-588. https://doi.org/10.1017/S0022029900017611

Law, B. A., Andrews, A. T., \& Sharpe M. E. (1977). Gelation of ultra-high temperature-sterilised milk by proteinases from a strain of Pseudomonas fluorescens isolated from milk. Journal of Dairy Research, 44, 145-148. https://doi.org/10.1017/S0022029900020057

Mitchell, S. L., \& Marshall, R. T. (1989). Properties of heat stable proteases of Pseudomonas fluorescens: Characterisation and hydrolysis of milk proteins. Journal of Dairy Science, 72, 864-874. https://doi.org/10.3168/jds.S0022-0302(89)79179-7

Nicodème, M., Grill, J. P., Humbert, G., \& Gaillard, J. L. (2005). Extracellular protease activity of different Pseudomonas strains: dependence of proteolytic activity on culture $\begin{array}{llll}\text { conditions. Journal } \text { Of Applied } & \text { Microbiology, 99, }\end{array}$ https://doi.org/10.1111/j.1365-2672.2005.02634.x

Nielsen, S. S. (2002). Plasmin system: characteristic, roles, and relationships. Journal of Agriculture and Food Chemistry, 50, 6628-6634. https://doi.org/10.1021/jf0201881

Patel, T. R., Jackman, D. M., Williams, G. J., \& Martlett, F. M. (1986). Extracellular heat resistant proteases of psychrotrophic Pseudomonads. Journal of Food Protection, 49, 183-188. https://doi.org/10.4315/0362-028X-49.3.183

Renner, E. (1988). Storage stability and some nutritional aspects of milk powders and ultra-high temperature product at high ambient temperatures. Journal of Dairy Research, 55, 125-142. https://doi.org/10.1017/S0022029900025942 


\section{Macrothink}

Schokker, E. P., \& Van Boekel, M. A. J. S. (1997). Production, purification and partial characterisation of the extracellular proteinase from Pseudomonas fluorescens $22 \mathrm{~F}$. International Dairy Journal, 7, 265-271. https://doi.org/10.1016/S0958-6946(97)00008-3

Snoeren, T. H. M., \& Van Riel, J. A. M. (1979). The properties of $\alpha_{\mathrm{S2} 2}$-group casein. Zuivelzicht, 71, 766-768.

Stepaniak, L. (2004). Dairy enzymology. International Journal Of Dairy Technology, 57, 153-171. https://doi.org/10.1111/j.1471-0307.2004.00144.x

\section{Copyright Disclaimer}

Copyright for this article is retained by the author(s), with first publication rights granted to the journal.

This is an open-access article distributed under the terms and conditions of the Creative Commons Attribution license (http://creativecommons.org/licenses/by/3.0/). 